\title{
The law of restitution: taking stock
}

\author{
by The Rt Hon The Lord Millett
}

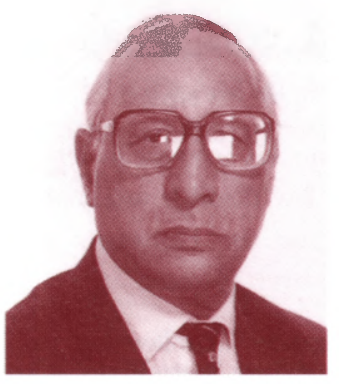

Rt Hon The Lord Millen

Despite the recent decision of the House of Lords in the Guinness Mahon case, which provided answers to some unanswered questions in the difficult area of restitution, many other questions still remain. In this article Lord Millett describes the current 'state of play', detailing in particular some of the remaining areas of possible controversy.

$\mathrm{T}$ the case of Westdeutsche Landesbank Girozentrale v Islington London Borough Council ([1996] AC 669) left unanswered the difficult question of precisely what was the ground of restitution in that instance. Was it want of consideration, as the Court of Appeal held? Was it total failure of consideration, as Lord Browne - Wilkinson suggested? Was it partial failure of consideration, which was my own preferred ground? Or was it mistake of law? The subsequent House of Lords decision in Guiness Mahon \& Co Ltd $v$ Kensington and Chelsea Royal London Borough Council ([1998] 2 All ER 272) answered this and other questions raised, but more remain to be addressed in this most difficult area of law.

\section{COMMON LAW \& EQUITY}

In this article I intend to concentrate on two questions which lie at the intersection of restitution and equity. First, is the application of the equitable tracing rules subject to a requirement that there must be a fiduciary relationship which permits the assistance of equity to be invoked? Secondly, when is a proprietary remedy available for a restitutionary claim?

Before attempting to answer these questions I wish to draw attention to one particular matter. The greatest single difficulty which English judges face in developing a coherent law of restitution lies in the duality of English law - in the division between common law and equity. The law of restitution was developed separately in the common law courts and the Court of Chancery. Yet they dealt with very similar kinds of case. They both dealt, for example, with claims for the repayment of money paid by mistake. They both dealt with rogues who embezzled money and gave it to their mistresses or used it to pay their gambling debts. They adopted very similar approaches to resolve the issues which arose, but they used different language and sometimes applied different standards. This is because they had different concepts of property and provided successful suitors with different remedies. Recognition of the fact that cases previously thought to have no connecting feature are based on a single, unifying principle - the reversal of unjust enrichment - is gradually enabling the law to be rationalised and older and however much we may wish to unify the law of restitution, we must reserve and distinguish between the legal and equitable concepts of property.

\section{THE LAW OF RESTITUTION}

The structure of the law of restitution is now firmly established. It has two main divisions: unjust enrichment by subtraction (or autonomous unjust enrichment) and unjust enrichment by wrongdoing (or dependent unjust enrichment). But unjust enrichment by subtraction can also be subdivided, for it covers two quite different kinds of case. There is the usual two-party case, in which A pays money or transfers property to $\mathrm{B}$ and afterwards claims to recover it because the payment or transfer was made (for example) by mistake. The swap cases are of this character, as are most of the cases which have recently been considered by the House of Lords.

But there is another kind of case which is increasingly common. This is the three-party case, in which A has power to deal with B's property and wrongfully transfers legal title to the property to $\mathrm{C}$. In such a case B sues to recover his own property; in civil law terms, he vindicates his title. German law locates such cases in the law of property, not unjust enrichment. Because English law recognises that legal title has passed, most English commentators have in the past treated these cases as falling within the law of restitution, though this has recently become controversial. Some argue that these cases are cases of unjust enrichment; others that they are part of the law of restitution but do not respond to unjust enrichment; others that they are not part of the law of restitution at all. I have to say that judges are profoundly uninterested in this kind of dispute. They take the pragmatic view that classification is important only as an aid to analysis and where correct classification is capable of affecting the outcome of the dispute.

\section{Two- and three-party cases distinguished}

It is important, however, to distinguish between the two-party and three-party cases because they are governed by different rules. The ground of restitution in the three-party cases is called 'ignorance' by Professor Birks and 'powerlessness' by Professor 
Burrows, in what appears to be an attempt to include theme within the restitutionary scheme. I prefer to call the ground of restitution 'want of title', which some will assume shows that 1 incline towards membership of the vindication of property rights school. But this does not matter. What does matter is that we should recognise that the three-party cases are subject to special rules:

(1) The bona fide purchaser defence is limited to this kind of case; it has no part to play in the two-party case. In this it differs from the change of position defence, which applies to both kinds of case.

(2) In the two-party case, where the defendant receives the property directly from the plaintiff, there is no need for the plaintiff to undertake the tracing exercise in order to prove that the defendant's enrichment was at his expense. The plaintiff does not have to prove his title to the property, because the defendant is in no position to dispute it; his right to retain the property depends on the plaintiff having the right to deal with it. But the plaintiff does have to undertake the tracing exercise in the three-party case, where the defendant does not receive the property directly from the plaintiff. In the absence of a direct nexus, the plaintiff has to prove that the property which the defendant received represents 'his property and not the property of someone else'

\section{MERELY A PROCESS}

Tracing is not a right or remedy ... It is merely the process by which the plaintiff identifies some asset ... as sufficiently representing an asset which formerly belonged to him.

\section{TRACING}

This brings me to the first of the two questions with which I wish to deal, which is concerned with tracing. It is the received wisdom that there are different rules for tracing at common law and in equity; that the equitable rules are superior, because (for example) the common law cannot trace into or out of a mixed bank account; but that there must be some fiduciary or trust relationship to justify the application of the equitable tracing rules.

There is binding authority of the Court of Appeal for all these propositions. In Re Diplock [1948] Ch 465 at p. 518 that court held that the common law and equity proceeded upon different theories of tracing and that, unlike equity, the common law cannot trace money which is paid into a mixed bank account, that is to say an account into which other money is paid whether before or after the money which is the subject of the tracing exercise. In Agip (Africa) Ltd v Jackson [1991] Ch 547 at p. 566 the Court of Appeal held that it is a precondition of the right to trace in equity that there must be a fiduciary relationship which calls the equitable jurisdiction into being. In his book on tracing, Lionel Smith has convincingly argued that each of these propositions rests upon inadequate authority and that none of them can be supported in principle.

I have never understood why it should be thought that the common law cannot trace through a mixed bank account. I have suggested that the real difficulty is not with tracing but with following. Where A wishes to trace the credit in his bank account at bank X into B's credit in his bank account at bank Y, A has to undertake two exercises. He has to trace and follow. He has to follow the money from hand to hand - from $A$ to $B$ - as well as trace out of bank $\mathrm{X}$ and into bank $\mathrm{Y}$. Where the money is paid by cheque there is no difficulty in following the cheque from $\mathrm{A}$ to $\mathrm{B}$; the only question is whether $\mathrm{A}$ can trace the money standing to his credit at bank $X$ into the cheque and the cheque into its proceeds which are represented by the money credited to B's account at bank Y. But this analysis will not help where there is an electronic transfer of funds because there is nothing to follow. We speak of tracing the money; but we speak metaphorically. No money moves through the clearing system. All that happens is that A's account is debited and, as a result of a series of consequential credits and debits, B's account at a different bank is credited. The credits and debits between the banks are netted off within the clearing system and any so-called money flows may be in the opposite direction. Equity does not follow the money; there is no money to follow. It identifies the money credited to B's account as representing the money debited to A's account because the credit and debit are causally and transactionally linked. The question is whether the common law does the same.

I do not think that we need to answer this question now that we have at last recognised the nature of the tracing exercise. Tracing is not a right or a remedy. It has nothing to do with the nature of the claim. It is merely the process by which the plaintiff identifies some asset, in the hands of the defendant, as sufficiently representing an asset which formerly belonged to him. The new asset is treated as a substitute for the original asset and is subject to the same claims. These need not be proprietary. Tracing may be necessary in order to establish the availability of a personal claim.

Given the nature of the tracing exercise, it is self-evident that we do not need two sets of tracing rules, one in aid of a claim at common law and one in aid of a claim in equity, each with different defects. As Lionel Smith has observed, there is nothing particularly legal or equitable about the tracing process. There is no logic in requiring the existence of a fiduciary or trust relationship as a precondition of the right to apply the equitable tracing rules. The rule is probably based on a misunderstanding of what the Court of Appeal said in Re Diplock [1948] Ch 465 at p. 520-537. The court insisted on the necessity of establishing, as a starting point,

'the existence of a fiduciary or quasi-fiduciary duty or of a continuing right of property recognised in equity ...'.

This was not a precondition for the application of equity's tracing rules, but a precondition for the availability of a proprietary claim. The remarks were made in the context of a long passage in which the court was describing what was necessary to 'give rise to the equitable right of property'. Insistence on the existence of a fiduciary relationship or continuing right of property recognised by equity is justified as a precondition to the existence of a proprietary claim; such a claim must have what Professor Birks calls 'a proprietary base'. If proprietary remedies are made generally available for breach of purely personal rights the difference between personal and proprietary rights is dangerously eroded.

The best way forward, in my opinion, is either to assert, with Lionel Smith, that there is nothing either legal or equitable about 
the tracing exercise, and that there is only one set of rules which is applicable both at common law and in equity; or to assert with Viscount Haldane LC in Sinclair v Brougham [1914] AC 398 at p. 421 that the equitable tracing rules form part of equity's auxiliary jurisdiction and are available to support a common law claim. On either footing no further time need be wasted on trying to breathe life into the common law tracing rules, which can be left to fall into disuse, as the common law action for account did centuries ago. The way will be open to a unified law of restitution.

\section{AVAILABILITY OF A REMEDY}

This leaves the second and more difficult question: when is a remedy available for a restitutionary claim? Only equity provides proprietary remedies, so the answer must be found in equitable doctrine. The law of restitution tells us only whether the personal remedy of account and payment is available. In order to discover whether there is a proprietary remedy we must turn to the law of property, and specifically to that part of the law of property which falls within the province of equity.

There is no doubt that proprietary relief is available in the three-party cases where the ground of restitution is want of title. It seems that it may also be available in some other situations, but the criteria for its availability are unclear. The Canadian Supreme Court makes it widely available; indeed, it is the primary remedy in Canada, which has adopted the so-called remedial constructive trust. The English and Australian courts have so far rejected the remedial constructive trust. They are likely to retain the personal remedy as the primary remedy, and allow a proprietary remedy only when particular conditions are satisfied.

This question is usually discussed in terms of the constructive trust. This is unfortunate, for the expressions 'constructive trust' and 'constructive trustee' are used in a variety of different senses, and they serve only to cause confusion. The expression 'constructive trustee', for example, has at least six different meanings:

(1) A person who assumes the role of a trustee and takes it upon himself to deal with the trust property on behalf of the beneficiaries although he has not been formally appointed as such. He is sometimes called a 'trustee de son tort'. He is really a de facto trustee rather than a constructive trustee, for he is a trustee in the fullest sense of the term. Only formal appointment is lacking.

(2) A director of a company or other fiduciary in possession or control of property belonging to another, who does not have legal title, and so is not strictly a trustee. He is in an analogous position and is treated as if he were a trustee. He is really a quasi-trustee.

(3) A person in a fiduciary position who abuses the trust and confidence reposed in him in order to obtain his principal's property for himself. He is properly described as a constructive trustee, for he holds the property from the moment he obtains it on constructive trust for his principal. A constructive trust arises by operation of law whenever the circumstances are such that it would be unconscionable for the owner of property (usually but not necessarily the legal estate) to assert his own beneficial interest in the property and deny the beneficial interest of another. Well known examples of such a constructive trust are McCormick v Grogan (1869) 4 App Casd 82 (a case of a secret trust) and Rochefoucauld v Boustead (1897) 1 Ch 196 (where the defendant agreed to buy property for the plaintiff but the trust was imperfectly recorded). Another example is Pallant $v$ Morgan (1953) Ch 43 (where the defendant sought to keep for himself property which he had agreed to buy for both parties).

This third group differs from the first two in that the defendant seeks to keep the property for himself, but is not allowed to do so. But the plaintiff does not impugn the transaction by which the defendant obtained the property. $\mathrm{He}$ alleges that the circumstances in which the defendant obtained it make it unconscionable for him to deny that he holds it in trust.

However, in each of these first three groups the trust is a real trust. The trustee is a real trustee and is subject to fiduciary obligations. It was classified as an express trust for limitation purposes, though it was nothing of the kind. Every fiduciary relationship is a voluntary relationship. No one can be compelled to enter into a fiduciary relationship or accept fiduciary obligations. In the first two groups the trustee willingly accepts his role and the fiduciary obligations which it entails. In this third group he does not; but he voluntarily places himself in a position where he is obliged by equity to act in the interests of the beneficiaries and not his own.

(4) Unfortunately the expression 'constructive trust' is also confusingly used of anyone who holds property on an implied trust, whether constructive or resulting. The legal owner who holds property on a resulting trust is not normally described as a 'resulting trustee'. It is customary to call him a constructive trustee.

(5) To add to the confusion, the expression 'constructive trustee' is also used to describe any defendant who is liable to be subjected to an equitable proprietary remedy. The court declares him to be a constructive trustee and orders him to transfer the trust property in specie to the plaintiff. But to say that he is a constructive trustee of the property is only another way of saying that he is liable to transfer it in specie to the plaintiff. The defendant is not a true trustee, for he owes no fiduciary obligations to the plaintiff.

The commonest example of this kind of constructive trust arises on the sale of land. It is well established that a contracting vendor of land holds the land on a constructive trust for the purchaser. But he is not a fiduciary. The constructive trust is only another way of saying that the vendor's undertaking to convey the land to the purchaser is specifically enforceable. This results in the separation of the legal and equitable ownership, but it creates no fiduciary relationship between the parties. In 
these last two groups the expression 'constructive trust' is used in a remedial sense to describe a particular kind of proprietary remedy, and even as shorthand for saying that proprietary relief is available in equity. In fact the constructive trust is only one form of proprietary remedy which equity makes available. The equitable charge and equitable subrogation are two others.

Thus the expression 'constructive trust' may be used in an institutional sense, when it is used in contra-distinction to other kinds of trust such as the express or resulting trust; or in a remedial sense, when it is used in contra-distinction to other proprietary remedies such as a charge or subrogation or to purely personal remedies such as equitable compensation or account.

(6) So far, the constructive trust arises in the context of equity's exclusive jurisdiction and yields a proprietary remedy. Unfortunately, however, it is also used in a completely different sense to justify the intervention of equity to grant relief against fraud. Such relief is ahways personal and takes the form of equitable compensation. It may arise in the course of equity's exclusive jurisdiction, as in the cases of knowing assistance, where the defendant is made liable to account 'as constructive trustee' because he is implicated in a breach of trust committed by others. But it seems it may also arise in the course of equity's concurrent jurisdiction, where equity awards compensation more generally for fraud. These cases differ from the others, for the plaintiff impugns the transaction by which the defendant obtained or dealt with the property. The expression 'constructive trust' is misleading, for there is no trust and the defendant is not a trustee. The expression is 'nothing more than a formula for equitable relief' (see Selangor United Rubber Estates Ltd ${ }_{v}$ Cradock [1968] 1 WLR 1555 at p. 1582 per Ungocd-Thomas J). We would avoid confusion if we were to drop the reference to 'constructive trustee' and say that the defendant was 'liable to account in equity'.

\section{Three-party cases}

Given these various meanings of the expression 'constructive trust', we would be well advised to drop it from the vocabulary of subtractive unjust enrichment altogether, and ask simply whether the plaintiff is entitled to a proprietary remedy. In the three-party case, where the plaintiff traces his property into the hands of the defendant there is no doubt that he is entitled to proprietary relief. Traditionally he asks the court to declare that the defendant is a constructive trustee of the property and to restore the property in specie. But the usage is particularly misleading for, as Dr Chambers has convincingly demonstrated, the trust which is operating is not a constructive trust at all but a resulting trust. This is important, because it avoids the injustice of subjecting the defendant to fiduciary obligations.

\section{Two-party cases}

The question then, is whether a proprietary remedy is ever available in the two-party case and, if so, what criteria determine its availability. One answer suggests itself immediately: when the ground for restitution is want of title. This is not in fact confined to the three-party case, as I may appear to have suggested. There are two kinds of two-party case where there clearly is a proprietary claim. One is where there is a defect in the payment or transfer itself. Where this is ultra vires the transferor, illegal or void, no title passes to the recipient. But the defect must be in the actual payment or transfer itself. It is not sufficient that the payment or transfer is, for example, for an illegal purpose. Unless the payment or transfer itself is illegal, title passes. The same applies a fortiori to payments or transfers for ultra vires purposes.

The other is merely an extension of the three-party case. The rule of equity is that the beneficial interest is not defeated by a breach of trust or fiduciary duty. It is enforceable against anyone who takes the property in which the interest subsists except a bona fide purchaser for value without notice. Liability to make restitution is strict, for it is not fault-based. There is no need for the principal to rescind the transaction in order to revest the beneficial interest; it is as if it never left him, for it never accompanied the legal title. But if the fiduciary cannot pass the beneficial ownership to a third party, he equally cannot take it for himself. So a fiduciary who acquires his principal's property in breach of his fiduciary duty is liable to restore it in specie to his principal. An example of such a case is Stump v Gaby (1852) 2 De G M\&G 623. A solicitor bought land from his client in circumstances which made the conveyance liable to be set aside on equitable grounds. The client then devised the land by his will. Lord St Leonards LC held that the land passed under the will. The client retained a devisable interest in the land, for in the view of this court he remained the owner.

Since the client was able to devise the land by his will he clearly retained an equitable interest in the land, presumably by way of resulting trust. But it was not treated as an equitable interest for all purposes. When it came to questions of priority it was classified as a mere equity, not binding a bona fide purchaser of an equitable interest in the land without notice: Phillips v Phillips (1862) 4 De G F\&J 208. The cases are discussed in Latec Investments Ltd $v$ Hotel Terrill Pty Ltd (1965) 113 at p. 265. This refinement need not detain us.

The main class of two-party restitutionary case, however, is where the plaintiff pays away his money by a valid payment, fully intending to part with the beneficial interest to the recipient, but his intention is vitiated by some factor such as fraud, misrepresentation, mistake and so on. In all these cases the beneficial interest passes, but the plaintiff has the right to elect whether to affirm or rescind the transaction. If he elects to rescind it, it is usually assumed that the beneficial title revests in the plaintiff retrospectively, and that the plaintiff can maintain a proprietary claim. But the recipient cannot anticipate his decision. Pending the plaintiff's election to rescind, the recipient is entitled - and may be bound - to treat the payment as effective. The plaintiff's subsequent rescission does not invalidate or render wrongful transactions which have taken place in the meantime on the faith of the receipt.

\section{RESCISSION OR RESULTING TRUST?}

It is tempting to equate the position with that which arises in the three-party case or its extension, the two-party case where the ground for restitution is want of title. Dr Chambers does so in his book on resulting trusts. He even suggests that the equity to rescind is in reality 'a resulting trust in disguise'.

I venture to disagree with this analysis. Rescission and the resulting trust are two different equitable responses to unjust enrichment and they need to be kept separate. In the Westdeutsche 
Landesbank case, Lord Browne-Wilkinson explained why a payment by mistake does not give rise to a resulting trust. A resulting trust arises whenever the legal estate is transferred but the person at whose expense it is transferred does not intend the beneficial interest to pass to the recipient. It is defeated by evidence that the person at whose expense the property has been transferred intended to make a gift or loan; but these are not the only circumstances in which a resulting trust may be rebutted. It may be rebutted by any explanation which demonstrates an intention to pass the beneficial interest to the recipient. Evidence that he transferred the property by mistake, for example, or for a consideration which has failed, rebuts the resulting trust

Dr Chambers rejects the distinction between property transferred or obtained in breach of fiduciary duty and property obtained by a transaction which is voidable for mistake, misrepresentation and the like. But there is a real distinction between property obtained, albeit improperly, by a transaction at arms' length and with the knowledge and consent of the beneficial owner, and property obtained without his knowledge and consent by a fiduciary exploiting his position for his own benefit. In the second kind of case, as we have seen, the plaintiff does not have to rescind the transaction in order to revest the beneficial title in himself; it is treated as never having left him. Of course he must elect whether to make a claim, and if he waits too long his claim may be barred by laches and acquiescence. But in the meantime he has a transmissible equitable interest in the property arising by way of resulting trust.

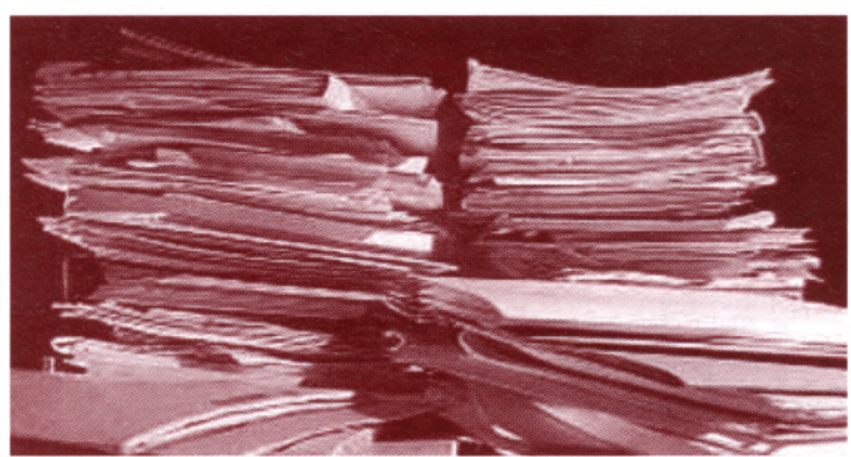

In the first kind of case the position is very different. The transaction stands in equity as well as at law until rescinded. Pending rescission the recipient has the whole legal and beneficial interest in the property, though his beneficial title is defeasible. There is no fiduciary relationship. The defeasible nature of the transferee's title should not inhibit his use of the property. Any right which the transferor has to retransfer in specie after rescission, is best regarded not as a response to a constructive or resulting trust, but as part of the working out of the equitable remedy of rescission. If this is the correct analysis, then the right to retransfer in specie is a form of specific performance which equity makes available because a money judgment is an inadequate remedy, and this means that it should be confined to cases of land or other property of unique value to the transferor.

What distinguishes the two cases is not the presence of a fiduciary relationship. 1t may be present in both. Nor is it the distinction between the two-party case and the three-party case. It is the distinction drawn by Brennan J in Daly $v$ Sydney Stock Exchange Ltd (1986) 160 CLR at p. 271 between property transaction, and property obtained in breach of fiduciary duty.

Can this analysis be supported by the authorities? I believe that it can. Dr Chambers cites five authorities in support of his thesis that a proprietary remedy is available whenever money is paid or property is transferred by a voidable transaction which is afterwards rescinded. The authorities are: Stump v Gaby; Gresley v Nousley (1859) 4 De G\&J 78; Dickinson v Burrell (1866) 1 Eq 337; Melbourne Banking Corp v Brougham (1882) 7 App Cas 307 and Phillips $v$ Phillips. With one exception they are all cases where a conveyance of land was set aside on equitable grounds for breach of fiduciary duty. They can all be justified on either of the two grounds I have mentioned. The one exception is the Melbourne Banking case, where an assignment of the equity of redemption in land was set aside for misrepresentation. That can be supported on my thesis either on the ground that the subject matter of the transaction was land, or that it was itself the creature of equity. None of them is authority for any wider availability of a proprietary remedy for mistake or misrepresentation.

There remains a residue of other cases where the obligation to make restitution arises from other causes. These need to be considered separately but they support my thesis. It is sufficient to take one example: the claim to recover money paid in anticipation of a contract which does not materialise. If the plaintiff can overcome the main problem which he faces, that of showing that he did not knowingly take the risk that the contract would not materialise, he may have a personal claim to restitution. There is, however, no basis on which he can assert a proprietary claim unless he can establish a Quistclose trust. It is not sufficient to show that he paid the money for a purpose which has failed. He must show that he paid it to the intent that it should be used for the stated purpose and for no other purpose. This is what precludes the recipient from treating the money as his own and creates a trust in favour of the plaintiff.

\section{CONCLUSION}

So I suggest that there are two situations, and two situations only, in which proprietary restitutionary remedies are available for subtractive unjust enrichment. The first is where he can establish a continuing beneficial interest in the property to which he lays claim. Such an interest will almost invariably arise under a resulting trust. The second arises where the original transfer was voidable and has been rescinded and specific retransfer is ordered because monetary restitution would not be an adequate remedy. By confining proprietary relief to these cases we will be applying the true ratio of Re Diplock and distinguishing between cases where there is a breach of trust or fiduciary duty and other cases, not for the purpose of applying the equitable tracing rules, but for the purpose of allowing a proprietary remedy. In the absence of a right to specific reconveyance after rescission, which may depend on the nature of the property, it should be a necessary precondition for proprietary restitutionary relief. (c)

The Rt Hon The Lord Millett

Lord of Appeal in Ordinary

This article is based on a SALS lecture given by Lord Millett on 23 July 1998 at the Institute. 